\title{
KONTRIBUSI DINASTI ABBASIYAH BIDANG ILMU PENGETAHUAN
}

\author{
Dra. Salmah Intan, M.Pd.I. \\ Universitas Islam Negeri Alauddin Makassar \\ Email:Salmahintan57@gmail.com
}

\begin{abstract}
This article aimed to reveal the progress of Muslims in the fields of religion, philosophy, education and science in the era Abbasid Dynasty, they were: the history of the emergence of the Abbasids, and the progress achieved by the Abbasids in the fields of religion, philosophy, education and science.The Abbasid dynasty was officially established in $750 \mathrm{AD}$, founded by Abu Abbas al-Saffah who was assisted by Abu Muslim al-Khurasani by seizing the power from the previous dynasty (Banu Umayah). During the Abbasid dynasty, developments and advances in various fields were fairly rapid. At that time, Muslims had reached the peak of glory, both in the fields of economics, civilization and power. In addition, various branches of science have also developed, coupled with the many translations of books from foreign languages to Arabic. In the field of religious science, several scholars emerged in the field of law or fiqh with various schools. The field of hadith found efforted to trace and collect hadith andthe science of interpretation hadalso stood alone. In the field of science and technology, medical science or medicine had developed quite rapidly, which was marked by the establishment of medical schools which also established institutions in certain fields such as Bait al-Hikmah.
\end{abstract}

Ceywoards:Contribusion, Abbasid Dynasty, Scientific Knowledge

\begin{abstract}
Abstrak
Tulisan ini bertujuan mengungkapkan tentang kemajuan umat Islam dalam bidang ilmu agama, filsafat, pendidikan dan sains pada masa Dinasti Abbasiyah. Dinasti Abbasiyah secara resmi berdiri pada tahun 750 M., didirikan oleh Abu Abbas al-Saffah yang dibantu oleh Abu Muslim al-Khurasani dengan merebut kekuasaan dari dinasti sebelumnya (Bani Umayah). Pada masa itu, Umat Islam telah mencapai puncak kemuliaan, baik dalam bidang ekonomi, peradaban dan kekuasaan. Selain itu juga telah berkembang berbagai cabang ilmu pengetahuan, ditambah lagi dengan banyaknya penerjemahan buku-buku dari bahasa asing ke bahasa Arab. Dalam bidang ilmu agama, muncullah beberapa ulama dalam bidang hukum atau fikih dengan berbagai mazhab. Dalam bidang hadis ditemukan usaha-usaha untuk penelusuran dan penghimpunan hadis. Ilmu tafsir yang sudah berdiri sendiri. ilmu kedokteran atau pengobatan telah berkembang cukup pesat, yang ditandai dengan berdirinya sekolah kedokteran juga dibangun lembaga dalam bidang tertentu seperti Bait al-Hikmah.
\end{abstract}

Kata Kunci: Kontribusi,Dinasti Abbasiyah, Ilmu Pengetahuan 


\section{A. Pendahulan}

Sebagaimana peradaban Islam yang pernah mencapai puncak keemasannya pada masa dinasti Abbasiyah. Meski terdapat sejumlah perbedaan, para ahli sejarah banyak yang membagi periodisasi sejarah peradaban DinastiAbbasiyah yang berumur sekitar lima ratus tahun (750-1258 M / 132-656 H) ke dalam dua periode utama. Periode pertama, berlangsung antara tahun $750-945 \mathrm{M} / 132-334 \mathrm{H}$, dimana pada masa itu Dinasti Abbasiyah memiliki otoritas politik yang sangat kuat dan kemudian mampu melahirkan sebuah kemajuan peradaban yang disebut-sebut sebagai era keemasan (the Golden Age). ${ }^{l}$ Akan tetapi, periode ini juga sekaligus mencatat munculnya benih-benih kemunduran dan kelemahan politik yang terjadi di paruh akhir masa ini.

Sedangkan periode kedua (945-1258M) adalah rentang waktu dimana Dinasti Abbasiyah secara faktual mengalami kemunduran politik dan para khalifah kehilangan otoritas kekuasaanya terhadap sejumlah wilayah dibarengi dengan lahirnya negara-negara kecil (duwaylät) yang memerdekakan diri. ${ }^{2}$ Karakteristik lain dari periode ini adalah masih terlihatnya sisa-sisa pengaruh kemajuan peradaban Islam era keemasan yang terwujud dalam perkembangan berbagai disiplin keilmuan (ulūm), pembangunan ('umrān), tercapainya kesejahteraan, hingga pada level berikutnya yang bersifat negatif yakni menggejalanya gaya hidup bermewahan (taraf). Periode Dinasti Abbasiyah ini berakhir pada tahun 1258 M ketika Baghdad jatuh ke tangan bangsa Mongol di bawah komando Hulagu Khan. ${ }^{3}$

Pembagian sejarah Abbasiyah sebagaimana model di atas, meski diakui oleh beberapa kalangan -seperti Eric Hanne sendiri- kurang tepat, ternyata mampu mempengaruhi nature atau gaya studi modern terhadap Dinasti Abbasiyah, dimana mayoritas fokus kajiannya lebih banyak dititikberatkan pada periode pertama.

Pada masa dinasti Abbasiyah, perkembangan maupun kemajuan-kemajuan dalam berbagai bidang sudah terbilang pesat. Pada masa itu, Umat Islam telah mencapai puncak kemuliaan, baik dalam bidang ekonomi, peradaban dan kekuasaan. Selain itu juga telah berkembang berbagai cabang ilmu pengetahuan, ditambah lagi

${ }^{1}$ Badri Yatim, Sejarah Peradaban Islam (cet. 23; Jakarta: Rajawali Press, 2011), h. 50.

${ }^{2}$ Badri Yatim, Sejarah Peradaban Islam. h. 82.

${ }^{3}$ Nurcholis Madjid, Khazanah Intelektual Islam, (Jakarta: Bulan Bintang, 1984), h. 35. 
dengan banyaknya penerjemahan buku-buku dari bahasa asing ke bahasa Arab. Fenomena ini kemudian yang melahirkan cendikiawan-cendikiawan besar yang menghasilkan berbagai inovasi baru di berbagai disiplin ilmu pengetahuan. ${ }^{4}$

Diantarannya, untuk bidang keilmuan sudah berkembang. Di Bagdad, dibuka jasa penerjemahan. Bagi penerjemah buku-buku bahasa asing, akan dibayar dengan emas seberat buku yang diterjemahkan. Selain itu, di Baitul Hikmah, terdapat 400 ribu judul buku.

Dinasti Abbasiyah merupakan dinasti Islam yang paling berhasil dalam mengembangkan peradaban Islam.Para ahli sejarah tidak meragukan hasil kerja para pakar pada masa pemerintahan dinasti Abbasiyah dalam memajukan ilmu pengetahuan dan peradaban Islam.Makalah ini, dengan menyinggung secara ringkas periodisasi seperti diatas,dansecara spesifik akan membahas dan memilah era kemajuan ilmu dan peradaban yang dicapai oleh Dinasti Abbasiyah.

\section{B. Kemunculan Dinasti Abbasiyah}

Sekitar tahun 747 M., Abbasiyah telah siap bergerak. Beberapa perkampungan di Khurasan, Abu Muslim, seorang agen Abbasiyah, berhasil merekrut pendukung yang dibutuhkannya. Beberapa perkampungan tersebut utamanya dihuni oleh para penduduk Arab dari kalangan Khurasan yang telah menjadi masyarakat petani, yang mana mereka menanggung pajak dan diperlakukan sebagai warga taklukan. Mereka adalah masyarakat yang kepadanya pihak Umayyah menjanjikan pembaharuan sistem pajakdan sekaligus tidak memenuhi janji tersebut.Sekarang, mereka siap untuk memberontak. Khurasan merupakan sebuah ajang agitasi politik dan menjadi harapan eskatologis. Dalam kesempatan seperti ini, Abu Muslim menampilkan sebuah bendera warna hitam sebagai symbol perjuangannya menggalang masyarakat yang diinginkan oleh pihak Umayyah. ${ }^{5}$

Berdirinya dinasti Abbasiyah semakin tampak ketika pasukan tempur yang telah dikumpulkan Abu Muslim mengalahkan kekuatan Marwan (khalifah ke-8 dari akhir Umayyah). Kendatipun Marwan telah dikalahkan, akan tetapi dinasti Abbasiyah

${ }^{4}$ Badri Yatim, Sejarah Peradaban Islam (cet. 23; Jakarta: Rajawali Press, 2011), h. 51.

${ }^{5}$ Ira. M. Lapidus, A History of Islamic Societies diterjemahkan oleh Ghufran A. Mas'adi dengan judul, Sejarah Sosial Umat Islam Bagian Ke Satu dan Ke Dua (Cet. I; Jakarta: PT. Raja Grafindo Persada, 1999), h. 102 
belum berdiri, karena Marwan ketika itu digantikan oleh Yazid bin Malik (w. 724) dan kemudian berpindah lagi ke Hisyam (w. 740 M), yang ke duanya masih keturunan Bani Umayyah.

Dengan wafatnya Hisyam, dan suksesnya Abu Muslim menggalang perhatian masyarakat, maka semakin luas pula kebencian masyarakat terhadap Daulah Bani Umayyah dan mayoritas masyarakat menaruh perhatian kepada Bani Hasyim (keturunan dan keluarga Nabi saw.) yang merupakan alur keturunan Bani Abbas, dimana selama dalam kurun waktu yang lama mereka tidak pernah terlibat dan dilibatkan dalam dunia pemerintahan.

Di samping Abu Muslim, Abu Abbas al-Shafah yang merupakan tokoh utama Bani Abbas melancarkan propaganda dan keberhasilannya merebut simpatisan,bermuara pada pelantikannya sebagai khalifah pertama Daulah Abbasiah pada tahun 750M. Dalam khutbah pelantikan yang disampaikannya di Mesjid Kufah, ia menyebut dirinya dengan al-Shaffah(penumpah darah) yang akhirnya menjadi julukannya. ${ }^{6} \mathrm{Al}-\mathrm{Shafah}$ pada awal kepemimpinannya berusaha dengan sekuat tenaga membasmi keluarga Bani Umayyah dengan kekuatan pedang/senjata.Target utamanya adalah menyerang pusat Daulah Umayyah di Damaskus.Dengan kemenangan yang diperolehnya, maka al-Shafah menjadikan Baghdad sebagai pusat pemerintahannya.

Dikatakan bahwa pengangkatan khalifah pada zaman Daulah Abbasiah tidak lagi melalui pemilihan, tetapi melalui sistem wilayah al-Ahdi (pengangkatan putera mahkota) yang ditentukan sebelumya oleh khalifah yang berkuasa. ${ }^{7}$ Sistem seperti ini berlanjut secara turun temurun hingga Daulah Abbasiah mengalami kehancuran.

Pada periode pertama bagi Dinasti Abbasiah terfokus pada upaya-upaya untuk memantapkan dan menjaga stabilitas Negara yang baru berdiri yang berpusat di Baghdad, yakni daerah yang terletak dekat bekas ibukota Persia. ${ }^{8}$ Dalam Ensklopedia Islam dikatakan bahwa corak dan pola hubungan social tidak lepas dari dasar dan

\footnotetext{
${ }^{6}$ Sayyed Mahmuddin Nasir, Islam: Its Concepts and History, diterjemahkan oleh Addang Affandi dengan judul Islam: Konsepsi dan Sejarahnya (Cet. IV; Bandung: Remaja Rosdakarya, 1994), h. 236

${ }^{7}$ H. Harifuddin Cawidu, Konsep Khilafah dalam Islam Dilihat dari Perspektif Politis dan Teologis dalam Tim Lakpesdam NU, Kumpulan Makalah Dr. H. Harifuddin Cawidu tahun 1987-2000 (Makassar: PMII Cabang Metro Makassar, 2003), h. 6

${ }^{8}$ Ahmad Amin, al-Tarikh al-Islam wa al-Hadharah al-Islamiyah, juz 3 (Mesir: Maktabah alNahdhah, t.th), h. 27.
} 
alasan dikobarkannya gerakan Abbasiah (al-Da'wah al-Abbasiah). ${ }^{9}$ oleh karena itu, dimaklumi jika pada awal berdirinya Abbasiah, aspek politik menjadi prioritas, yakni menegaskan dan mengokohkan eksistensinya seraya membersihkan seluruh antekantek Bani Umayyah.

Kaitannya dengan hal tersebut, para sejarawan membagi masa pemerintahan Bani Abbas menjadi lima periode. Periode pertama (132 H/750 M - 232 H/847 M) disebut periode pengaruh Persia pertama; period kedua (232 H/487 M- 334 H/945 M)) disebut masa pengaruh Turki pertama; periode ke tiga (334 H/945-447H/1055 M), masa kekuasaan dinasti Buwaihi dalam pemerintahan Khilafah Abbasiah. Periode ini disebut pula masa pengaruh Persia ke dua; periode ke empat (447H/1055 M - 590 H/1194), masa kekuasaan Bani Saljuk dalam pemerintahan Khilafah Abbasiah, biasanya disebut juga dengan masa pengaruh Turki muda; period ke lima (590 H/1194 M - $656 \mathrm{H} / 1258 \mathrm{M}$ ), masa khalifah bebas dari pengaruh dinasti lain,tetapi kekuasaannya hanya efektif disekitar kota Baghdad. ${ }^{10}$

\section{Kemajuan Ilmu Pengetahuan}

Ada beberapa prestasi yang menonjol yang pernah diraih oleh Dinasti Abbasiah, bukan hanya dalam bidang agama saja, tapi juga dalam bidang sains dan teknologi, filsafat, ekonomi dan bidang manajemen administrasi. Keberhasilan tersebut dapat dilihat sebagai berikut:

1. Bidang Ilmu Agama

Selain gerakan penerjemahan, kemajuan ilmu dan peradaban Era Abbasiyah juga ditandai dengan berkembangnya ilmu-ilmu keislaman, ilmu sosial dan sains.Di bidang ilmu-ilmu agama, Era Abbasiyah mencatat dimulainya sistematisasi beberapa cabang keilmuan seperti Tafsir, Hadits dan Fiqh.Khususnya sejak tahun 143 H, para ulama mulai menyusun buku dalam bentuknya yang sisitematis baik di bidang ilmu Tafsir, Hadits maupun Fiqh.

Hampir dapat dikatakan pada dekade Abbasiah kemajuan dalam bidang agama sangat fantastik. Dalam bidang hukum atau fikih misalnya telah lahir empat corak 1992), h. 3.

${ }^{9}$ Tim Penyusun IAIN Syarif Hidayatullah, Ensklopedi Islam (Cet. I; Jakarta:Djambatan,

${ }^{10}$ Badri Yatim, Sejarah Peradaban Islam, (Cet. II; Jakarta: LSIK dan PT. Raja Grafindo Persada, 1994), h. 49. 
mazhab yang masing-masing mazhab Hanafi, oleh Imam Abu Hanifah (w. 150 H), madzhab al-Syafi'i oleh imam Muhammad Idris al-Syafi'i 204 H) dan madzhab Hanbal (w. $241 \mathrm{H}) .{ }^{11}$ dalam bidang teologi, lahir aliran Mu'tazilah yang menjadi aliran resmi kerajaan. Aliran lain adalah Ahlussunnah wal Jama'ah yang dimotori oleh Abu Hasan al-Asy'ari dan Abu Mansur al-Maturudi. ${ }^{12}$ Dalam bidang hadis, juga ditemukan usaha-usaha untuk penelusuran dan penghimpunan hadis yangterpusat di Madinah, Mekkah, Basrah, Kufah dan lain-lain. ${ }^{13}$ Diantara ulama tersebut yang terkenal adalah adalah Ibn Jurayj (w. 150 H) yang menulis kumpulan haditsnya di Mekah, Mālik ibn Anas (w. 171) yang menulis Al-Muwatta' nya di Madinah, Al-Awza`i di wilayah Syam, Ibn Abi 'Urūbah dan Hammād ibn Salāmah di Basrah, Ma'mar di Yaman, Sufyān al-Tsauri di Kufah, Muhamad Ibn Ishāq (w. 151H) yang menulis buku sejarah (Al-Maghāzi), Al-Layts ibn Sa'ad (w. 175H) serta Abū Hanīfah.

Selanjutnya pada awal-awal abad ketiga, muncul kecenderungan baru penulisan hadits Nabi dalam bentuk musnad. Diantara tokoh yang menulis musnad antara lain Ahmad ibn Hanbal, 'Ubaydullah ibn Mūsa al-`Absy al-Kūfi, Musaddad ibn Musarhad al-Basri, Asad ibn Mūsā al-Amawi dan Nu’aym ibn Hammād alKhuzā’i.

Perkembangan penulisan hadits berikutnya, masih pada era Abbasiyah, yaitu mulai pada pertengahan abad ketiga, muncul trend baru yang bisa dikatakan sebagai generasi terbaik sejarah penulisan hadits, yaitu munculnya kecenderungan penulisan hadits yang didahului oleh tahapan penelitian dan pemisahan hadits-hadits sahīh dari yang dla`îf sebagaimana dilakukan oleh Al-Bukhari (w.256), Muslim (w.261), Ibn Mājah (w.273), Abu Dāwud (w.275), Al-Tirmidzi (w. 279), serta Al-Nasā’i (w.303).

Pada masa ini, ilmu Tafsir menjadi ilmu mandiri yang terpisah dari ilmu Hadis. Buku tafsir lengkap dari al-Fātihah sampai al-Nās juga mulai disusun. Menurut catatan Ibn al-Nadīm yang pertama kali melakukan penyusunan tafsir lengkap tersebut adalah Yahya bin Ziyād al-Daylamy atau yang lebih dikenal dengan sebutan

\footnotetext{
${ }^{11} \mathrm{~W}$. Wontgomery Watt, The Wajesty That Wan Islamic, diterjemahkan oleh Hariono dengan judul Kerajaan Islam, (Yogyakarta: Tiara wacana, 1990), h. 126

${ }^{12}$ Harun Nasution, Teologi Islam, (Jakarta: UI Press, 1986), h. 8

${ }^{13}$ Syuhudi Ismail, Pengantar Ilmu Hadis, (Bandung: Angkasa, t.th), h.107
} 
Al-Farrā. ${ }^{14}$ Tapi luput dari catatan Ibn al-Nadīm bahwa `Abd al-Razzāq ibn Hammam al-San’āni (w.211H) yang hidup sezaman dengan Al-Farā juga telah menyusun sebuah kitab tafsir lengkap yang serupa. ${ }^{15}$

Disiplin keilmuan lain yang juga mengalami perkembangan cukup signifikan pada era Abbasiyah adalah ilmu sejarah, yang awal penulisannya dilakukan oleh Ibn Ishāq (w. 152) dan kemudian diringkas oleh Ibn Hisyām (w. 218). Selanjutnya muncul pula Muhamad ibn `Umar al-Wāqidi (w. 207) yang menulis buku berjudul AlTārīkh al-Kabīr dan Al-Maghāzi.Buku yang pertama dinyatakan hilang, meski isinya masih direkam oleh sejarahwan Al-Tabari (838-923M). Sejarahwan lain yang datang berikutnya adalah seperti Muhamad ibn Sa'ad (w.230 H) dengan Al-Tabaqāt alKubrā-nya serta Ahmad Ibn Yahya al-Balādhuri (w.279) yang menulis Futūh alBuldān. ${ }^{16}$

2. Bidang Sains dan Teknologi

Kemajuan yang dicapai oleh umat Islam di Era Abbasiyah tidak hanya terbatas pada ilmu-ilmu agama atau yang biasa diistilahkan dengan ulüm naqliyah saja, melainkan juga disertai dengan kemajuan ilmu-ilmu sains dan teknologi ( ulūm aqliyah). Bahkan jika dicermati, kemajuan sains di dunia Islam mendahului perkembangan ilmu filsafat yang juga berkembang pesat di era Abbasiyah. Hal ini bisa jadi merupakan buah dari kecenderungan bangsa Arab saat itu yang lebih mengutamakan penerjemahan buku-buku sains yang memiliki implikasi kemanfaatan secara langsung bagi kehidupan mereka (dzāt al-atsar al-māddi fì hayātihim) dibanding buku-buku olah pikir (filsafat).

Kemajuan yang dicapai pada era ini telah banyak memberikan sumbangan besar kepada peradaban manusia modern dan sejarah ilmu pengetahun masa kini. Dalam bidang matematika misalnya, ada Muhamad ibn Mūsa al-Khawārizmi sang pencetus ilmu algebra. Algoritma, salah satu cabang matematika bahkan juga diambil

\footnotetext{
${ }^{14}$ Ibn al-Nadīm al-Baghdādi, Al-Fihrist, h. 73; Ahmad Shalabi, Mawsū ah al-Tārikh al-Islāmi

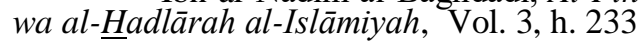

${ }^{15}$ Lihat Al-Mawsū 'ah al- 'Arabiyyah al- 'Alamiyah, entry: Tafsīr al-Qur'ān al-Karìm.

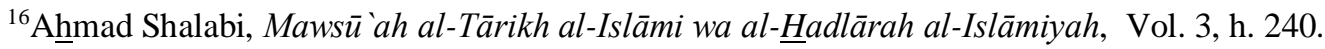


dari namanya. ${ }^{17}$ Astronomi juga merupakan ilmu yang mendapat perhatian besar dari kaum muslim era Abbasiyah dan didukung langsung oleh Khalifah Al-Mansūr yang juga sering disebut sebagai seorang astronom.Penelitian di bidang astronomi oleh kaum muslimin dimulai pada era Al-Mansūr ketika Muhamad ibn Ibrāhīm al-Fazāri menerjemahkan buku "Siddhanta" (yang berarti Pengetahuan melalui Matahari) dari bahasa Sanskerta ke bahasa Arab.Pada era Hārūn al-Rashīd dan Al-Ma'mūn sejumlah teori-teori astronomi kuno dari Yunani direvisi dan dikembangkan lebih lanjut. Tokoh astronom muslim yang terkenal pada era Abbasiyah antara lain Al-Khawārizmi, Ibn Jābir Al-Battāni (w. 929), Abu Rayhān al-Biruni (w.1048) serta Nāsir al-Dīn al-Tūsi (w.1274). ${ }^{18}$

Pada Dinasti Abbasiah ilmu kedokteran atau pengobatan dapat dikatakan cukup berkembang pesat.Ini ditandai dengan berdirinya sekolah kedokteran tingkat tinggi di Horaan Syiria.Pada sekolah ini, para pengajarnya mayoritas orang Iran, Syiria dan Yunani.Sementara Pelajar atau mahasiswanya berasal dari India.Pada masa ini pula diadakan penerjemahan buku dari bahasa Yunani ke bahasa Syiria. ${ }^{19} \mathrm{Pada}$ masa ini, beberapa ahli kedokteran seperti Ibnu Sina (Avicenna), al-Razi (Rhazes), Jabir dan Yuhanna ibn Maskawayh.

Era Keemasan Dinasti Abbasiyah juga mencatat penemuan-penemuan dan inovasi penting yang sangat berarti bagi manusia.Salah satu diantaranya adalah pengembangan teknologi pembuatan kertas. Kertas yang pertama kali ditemukan dan digunakan dengan sangat terbatas oleh bangsa China berhasil dikembangkan oleh umat Muslim Era Abbasiyah, setelah teknologi pembuatannya dipelajari melalui para tawanan perang dari Cina yang berhasil ditangkap setelah meletusnya Perang Talas.Setelah itu kaum Muslim berhasil mengembangkan teknologi pembuatan kertas tersebut dan mendirikan pabrik kertas di Samarkand dan Baghdad.Hingga pada tahun $900 \mathrm{M}$ di Baghdad terdapat ratusan percetakan yang mempekerjakan para tukang tulis dan penjilid untuk membuat buku.Perpustakaan-perpustakaan umum saat itu mulai bermunculan, termasuk perpustakaan peminjaman buku pertama sepanjang

\footnotetext{
${ }^{17}$ Muhamad al-Sādiq `Afífi, Tatawwur al-Fikr al-'Ilmi Inda al-Muslimīn, h. 93.

${ }^{18}$ Muhamad al-Sādiq `Afifi, Tatawwur al-Fikr al-'Ilmi Inda al-Muslimīn, h. 80.

${ }^{19}$ Oemar Amir Husin, Kultur Islam, (Jakarta: Bulan Bintang, 1975), h. 69.
} 
sejarah.Dari Baghdad teknologi pembuatan kertas kemuddian menyebar hingga $\mathrm{Fez}$ dan ahirnya masuk ke Eropa melalui Andalusia pada abad $13 \mathrm{M} .{ }^{20}$

3. Bidang Filsafat

Sebagai bias dari penerjemahan bahasa Yunani maka, melahirkan filosof Muslim seperti al-Kindi (w. 252 H), al-Farabi (w. 337 H), Ibnu Sina (w. 428 H). ${ }^{21}$ Dari kajian filsafat yang memadai, melahirkan ilmuwan Islam yang popular, seperti ilmuwan astronomi yang menemukan astrolabe, alat pengukur ketinggian bintang yang dipelopori oleh al-Farazi (w. 777 M). Ilmuwan lain adalah Umar Khayan, alBantani, al-Biruni dan lain-lain. Sedang dalam bidang matematika yang popular adalah al-Khawarizmi $(850 \mathrm{M}) .^{22}$

4. Perkembangan dalam bidang pendidikan

Dalam bidang pendidikan, pendidikan anak dimulai di rumahnya masingmasing.Ketika si anak mulai berbicara, si ayah wajib mengajarinya untuk untuk mengucapkan kalimat tauhid. Dan ketika ia berumur enam tahun ia mesti diajari untuk melaksanakan shalat wajib. Pada usia itu pulalah dimulainya pendidikan formal. ${ }^{23}$ Sebelum dinasti Bani Abbasiyah, pusat kegiatan dunia Islam selalu bermuara pada masjid.Masjid dijadikan center of education.Pada dinasti Bani Abbasiyah inilah mulai adanya pengembangan keilmuan dan teknologi diarahkan ke dalam ma'had. Lembaga ini kita kenal ada dua tingkatan, yaitu24 :

a. Maktab/kuttab dan masjid yaitu lembaga pendidikan terendah, tempat anak-anak remaja belajar dasar-dasar bacaan, menghitung dan menulis serta anak remaja belajar dasar-dasar ilmu agama.

b. Tingkat pendalaman, para pelajar yang ingin memperdalam Islam pergi ke luar daerah atau ke masjid-masjid, bahkan ke rumah gurunya. Pada tahap berikutnya, mulailah dibuka madrasah-madrasah yang dipelopori Nizhamul Muluk yang memerintah pada tahun 456-485 H. Lembaga inilah yang kemudian berkembang

\footnotetext{
${ }^{20} \mathrm{http}: / /$ en.wikipedia.org/wiki/Islamic_golden_age;

${ }^{21}$ Harun Nasution, Filsafat dan Mistisme dalam Islam, (Jakarta: Bulan Bintang, 1973), h. 69.

${ }^{22}$ Harun Nasution, Akal dan Wahyu, (Jakarta: UI Press, 1986), h. 65.

${ }^{23}$ Philip K. Hitti, History of the Arabs, (Jakarta:PT. Serambi Ilmu Semesta, 2008), h.512.

${ }^{24}$ Ajid Thohir, Perkembangan Peradaban di Kawasan Dunia Islam (Jakarta: PT. Raja
} Grafindo Persada, 2004), h. 50. 
pada masa dinasti Bani Abbasiyah.Pada lembaga pendidikan Islam yang pertama iniuntuk pengajaran yang lebih tinggi tingkatannyaadalah Baital-Hikmah.Selain berfungsi sebagai biro penerjemahan, lembaga ini juga dikenal sebagai pusat kajian akademis dan perpustakaan umum serta memiliki observatorium.

Kurikulum utamanya dipusatkan pada al-Qur'an sebagai bacaan utama dan hampir dalam seluruh kurikulum yang diajarkan, metode menghapal sangat dipentingkan.Padapendidikan dewasa tidak hanya dikembangkan dengan cara-cara yang sistematis atau dilembaga-lembaga formal, tetapi juga dilakukan dimesjidmesjid yang terdapat di semua kota muslim. Selain sebagai pusat pendidikan,mesjid juga berfungsi sebagai tempat penyimpanan buku-buku. ${ }^{25}$

Gerakan keilmuan pada dinasti Abbasiyah lebih bersifat spesifik, kajian keilmuan yang kemanfaatannya bersifat keduniaan bertumpu pada ilmu kedokteran, di samping kajian yang bersifat pada al-Qur'an dan al-Hadits, sedang astronomi, mantiq dan sastra baru dikembangkan dengan penerjemahan dari Yunani.Kemajuan dalam berbagai sektor di atas, tidak dicapai dalam waktu yang singkat, tapi, memakan waktu dan tenaga.Lebih dari itu dibutuhkan kesungguhan dari pelaksana Negara.

Kemajuan peradaban yang dicapai oleh Dinasti Abbasiyah pada hakekatnya tidak datang dari ruang hampa, melainkan pada titik yang paling penting merupakan buah dari pengaruh konsep-konsep dalam ajaran Islam itu sendiri. Hal ini diakui pula oleh beberapa penulis Barat semisal Vartan Gregorian dalam bukunya Islam: A Mosaic, Not a Monolith.Kesimpulan tersebut jika ditilik dari perspektif kajian sejarah peradaban berkesesuaian dengan teori yang menyatakan bahwa semangat yang dibawa oleh konsep keagamaan (al-fikrah al-dīniyyah) merupakan élan vital dan menjadi unsur paling penting terbangunnya sebuah peradaban.

Di samping itu, faktor lain yang secara lebih lanjut turut mempengaruhi kemajuan peradaban Dinasti Abbasiyah adalah interaksi masif kaum muslimin era Abbasiyah dengan komunitas-komunitas masyarakat di beberapa wilayah yang sebelumnya telah menjadi pusat warisan pemikiran dan peradaban Yunani seperti Alexandria (Mesir), Suriah, serta wilayah Asia Barat, khususnya Persia.

\footnotetext{
${ }^{25}$ Ajid Thohir, Perkembangan Peradaban di Kawasan Dunia Islam, h. 20.
} 
Dinasti Abbasiyah dengan cepat telah mampu menciptakan sebuah kemajuan ilmu dan peradaban yang menurut Dr. Ahmad Shalabi terwujud dalam tiga sektor yaitu menggeliatnya gerakan penulisan buku (harakat al-tasnīf), kodifikasi dan sistematisasi ilmu-ilmu keislaman, serta menjamurnya gerakan penerjemahan (harakat al-tarjamah) secara masif. Selain tiga hal di atas dapat ditambahkan pula perkembangan ilmu sains yang melahirkan tokoh-tokoh ilmuwan legendaris yang diakui tidak saja di dunia Muslim tetapi juga oleh kalangan akademisi Barat.

\section{Kesimpulan}

Masa pemerintahan bani Abbas, umat Islam berada pada masa keemasan dengan berbagai kemajuan antara lain; Dalam bidang ilmu agama, muncullah beberapa ulama dalam bidang hukum atau fikih dengan berbagai mazhab. Dan dalam bidang hadis ditemukan usaha-usaha untuk penelusuran dan penghimpunan hadis. Begitupula ilmu lainnya, seperti ilmu tafsir yang sudah berdiri sendiri. Dalam bidang sains dan tekhnologi, khususnya pada ilmukedokteran atau pengobatan telah berkembang cukup pesat, yang ditandai dengan berdirinya sekolah kedokteran tingkat tinggi. Dalam bidang filsafat, dari kajian ilmu filsafat itulah sehingga melahirkan ilmuwan Islam popular atau para filosof dan pemikirannya. Dan pada bidang pendidikan, ditandai dengan kurikulum utamanya dipusatkan pada al-Qur'an dan hadis, sertaberbagai lembaga pendidikan telah terbangun, mulai dari mesjid yang juga dijadikan tempat pengajaran/pendidikan selain tempat ibadah. Juga dibangunnya lembaga-lembaga dalam bidang tertentu seperti Bait al-Hikmah.

\section{DAFTAR PUSTAKA}

Ahmad Amin, al-Tarikh al-Islam wa al-Hadharah al-Islamiyah, (Mesir:Maktabah alNahdhah, t.th)

Ajid Thohir, Perkembangan Peradaban di Kawasan Dunia Islam, Jakarta: PT. Raja Grafindo Persada, 2004

Badri Yatim, Sejarah Peradaban Islam, (Cet. II; Jakarta: LSIK dan PT. Raja Grafindo Persada, 1994)

H. Harifuddin Cawidu, Konsep Khilafah dalam Islam Dilihat dari Perspektif Politis dan Teologis dalam Tim Lakpesdam NU, Kumpulan Makalah Dr. H. Harifuddin Cawidu tahun 1987-2000 (Makassar: PMII Cabang Metro Makassar, 2003) 
Harun Nasution, Akal dan Wahyu, (Jakarta: UI Press, 1986)

Harun Nasution, Filsafat dan Mistisme dalam Islam, (Jakarta: Bulan Bintang, 1973)

Harun Nasution, Theologi Islam, (Jakarta: UI Press, 1986)

Ibn al-Nadīm al-Baghdādi, Al-Fihrist, Ahmad Shalabi, Mawsū 'ah al-Tārikh al-Islāmi wa al-Hadlārah al-Islāmiyah, tth, Al-Mawsū 'ah al-'Arabiyyah al-'Ālamiyah, entry: Tafsìr al-Qur'ān al-Karìm.

Ira. M. Lapidus, A History of Islamic Societies diterjemahkan oleh Ghufran A. Mas'adi dengan judul, Sejarah Sosial Umat Islam Bagian Ke Satu dan Ke Dua (Cet. I; Jakarta: PT. Raja Grafindo Persada, 1999)

Muhamad al-Sādiq `Afïfi, Tatawwur al-Fikr al-'Ilmi Inda al-Muslimīn,tth

Oemar Amir Husin, Kultur Islam, (Jakarta: Bulan Bintang, 1975)

Philip K. Hitti, History of the Arabs, (Jakarta:PT. Serambi Ilmu Semesta, 2008),

Sayyed Mahmuddin Nasir, Islam: Its Concepts and History, diterjemahkan oleh Addang Affandi dengan judul Islam: Konsepsi dan Sejarahnya (Cet. IV; Bandung: Remaja Rosdakarya, 1994).

Syuhudi Ismail, Pengantar Ilmu Hadis, (Bandung: Angkasa, t.th)

Tim Penyusun IAIN Syarif Hidayatullah, Ensklopedi Islam (Cet. I; Jakarta:Djambatan, 1992)

W. Wontgomery Watt, The Wajesty That Wan Islamic, diterjemahkan oleh Hariono dengan judul Kerajaan Islam, (Yogyakarta: Tiara wacana, 1990) 